\section{Avaliação da resposta imune humoral a quatro esquemas de vacinação anti-rábica pré-exposição}

A raiva é um dos problemas de Saúde Pública, sendo letal em quase $100 \%$ dos casos. Mais de 20.000 mortes por raiva humana ocorrem por ano em todo o mundo e o cão é o principal transmissor na maioria dos casos. Por isto, diferentes esquemas de vacinação antirábica pós-exposição são utilizados, contudo, com relação aos esquemas pré-exposição não se tem determinado qual esquema induz a melhor resposta de anticorpos específicos após vacinação. Deste modo, o objetivo deste estudo foi avaliar a resposta humoral contra o vírus rábico, após aplicação da vacina anti-rábica Fuenzalida-Palacios utilizada em quatro esquemas pré-exposição. Neste estudo experimental a população foi constituída por estudantes de medicina veterinária da UFBA, sendo selecionados 113 indivíduos, distribuídos aleatoriamente nos quatro esquemas vacinais avaliados (I - Ministério da Saúde: 0, 2, 4, 28 dias; II - Alternativo 1: 0-2 doses, 4 dias; III TECPAR: 0, 7, 14 dias; IV - Alternativo 2: 0-2 doses, 7 dias). A titulação de anticorpos neutralizantes $(\mathrm{AcN})$ foi determinada usando o teste de soro-neutralização (TN) em camundongos nas amostras séricas coletadas no seguintes dias: $0,7,16,30$ e 60 . Resultados. $\mathrm{Na}$ última avaliação sorológica, por exemplo, os títulos, conforme o esquema, foram os seguintes em Ul/ml: I (1,96 $\pm 1,78)$, II $(0,62 \pm$ $0,93)$, III - $(7,13 \pm 7,82)$ e IV $(4,49 \pm 6,00)$. Na avaliação dos resultados dos quatro grupos vacinais, as melhores respostas foram obtidas com os esquemas vacinais III e IV. Todavia, com o esquema vacinal IV a totalidade dos indivíduos (100\%) foi respondedor (título $\geq$ $0,5 \mathrm{Ul} / \mathrm{ml}$ ), com a vantagem de neste esquema vacinal o indivíduo necessitar apenas de duas visitas à Unidade de Saúde. Conclusões: (i) os esquemas vacinais reduzidos, com 3 doses são uma boa alternativa para imunização pré-exposição; (ii) os esquemas reduzidos oferecem a vantagem de títulos sorológicos protetores num período curto de tempo; (iii) o

\section{Human antirabies pre-exposure immunization: evaluation of the humoral immune response in a four schedule study}

Rabies is one of the most serious public health problem. It is nearly $100 \%$ lethal disease. In the world, there are more than 20,000 deaths due to rabies every year, mostly transmited by dogs. Because of that, several different human antirabies post-exposure immunization schedules are used. However, there is no concensus about the best pre-exposure vaccination schedule to induce specific antibodies response. The objective of the present study is to evaluate the humoral immune response to the rabies virus using the vaccine Fuenzalida-Palacios under four different schedules of pre-exposure immunization. The experiment was carried out in a test group composed of Medical Veterinary students from the Federal University of Bahia (UFBA). One hundred and thirteen students were randomly selected for the study receiving one of the four schedule: (I - Ministry of Health: 0, 2, 4, 28 days; II - Alternativ 1: 0 -2 doses, 4 days; III - TECPAR: 0, 7, 14 days and IV - Alternative 2: $0-2$ doses, 7 days). On days $0,7,16,30$ and 60 titres of neutralized antibodies (AcN) were determined by using a sero-neutralizations (TN) test in mice. Results. The last serological evaluation showed titres according to each schedule for $\mathrm{IU} / \mathrm{ml}$ as follows: I (1.96 \pm 1.78$)$, II $(0.62 \pm 0.93)$, III - (7.13 \pm 7.82$)$ and IV $(4.49 \pm 6.00)$. The final analysis of the four immunization schedule showed that the best results were obtained from groups III and IV. In group IV all subjects (100\%) were responsive (titre $\geq 0,5 \mathrm{IU} / \mathrm{ml}$ ). In addition, group IV has the advantage of requiring only two visits for applications of the vaccine. Conclusions: (i) reduced three doses vaccine schedules are a good choice for pre-exposure immunization; (ii) the reduced vaccine schedules provide good serological protection in a shorter period of time; (iii) the vaccine schedule currently offered by the Ministry of Health (I) is not only more costly (four doses at different times) but it also does not provide better serological response than the reduced schedules (IV) or (III) with three doses. 
Revista da Sociedade Brasileira de Medicina Tropical 31:237-238, mar-abr, 1998.

esquema vacinal I recomendado pelo Ministério da Saúde, além de ser de custo maior (4 doses em tempos diferentes) não forneceu resposta sorológica superior aos esquemas reduzidos (IV) e (III) com três doses de vacina.

Jacy Amaral Freire de Andrade

Tese apresentada à Faculdade de Medicina da Universidade Federal da Bahia para obtenção do Título de Doutor.

Salvador, BA, Brasil, 1997. 